\title{
PENGARUH STRATEGI PEMBELAJARAN SUPERITEM TERHADAP KEMAMPUAN PEMECAHAN MATEMATIS SISWA PADA MATERI PtLSV KELAS VII SMP NEGERI 8 SINGKAWANG
}

\author{
Rika Wahyuni ${ }^{1)}$ Nindy Citroresmi Prihatiningtyas ${ }^{2)}$ \\ ${ }^{1)}$ STKIP Singkawang, Singkawang, Indonesia \\ Email: rikawahyuni142@gmail.com \\ ${ }^{2)}$ STKIP Singkawang, Singkawang, Indonesia \\ Email: Nindy.citroresmi@gmail.com
}

\begin{abstract}
Abstrak. Secara khusus penelitian ini bertujuan untuk mengetahui:1) Pengaruh Strategi Pembelajaran Superitem Terhadap Kemampuan Pemecahan Masalah Matematis Siswa pada Materi Pertidaksamaan Linear Satu Variabel Kelas VII, 2) untuk mengetahui seberapa besar pengaruh strategi pembelajaran superitem pada materi pertidaksamaan linear satu variabel kelas VII, 3) untuk mengetahui aktivitas belajar siswa saat diterapkan strategi pembelajaran superitem 4) untuk mengetahui minat siswa terhadap strategi pembelajaran superitem. Jenis penelitian yang digunakan adalah kuantitatif, bentuk penelitian the nonequivalent posstest-only control group design. Populasi penelitian adalah siswa kelas VII yang terdiri dari lima kelas. Sampel penelitian diambil menggunakan sampling jenuh maka didapat kelas VII A dengan jumlah siswa yaitu 26 siswa sebagai kelas eksperimen dan kelas VII B dengan jumlah siswa yaitu 26 siswa sebagai kelas kontrol. Hasil perhitungan kemampuan pemecahan masalah matematis siswa dengan menggunakan Uji independen sampel t-test terdapat perbedaan kemampuan pemecahan masalah matematis siswa antara kelas eksperimen dengan menggunakan strategi pembelajaran superitem dan kelas kontrol yang diberikan model pembelajaran langsung. Strategi pembelajaran superitem berpengaruh tinggi terhadap kemampuan pemecahan masalah matematis siswa yang diuji dengan menggunakan perhitungan Effect Size. Lembar observasi aktivitas belajar siswa dengan strategi pembelajaran superitem menggunakan perhitungan persentase frekuensi aktivitas. Hasil analisis menunjukkan adanya peningkatan aktivitas belajar siswa, di mana pada pertemuan pertama diperoleh persentasenya sebesar $84,54 \%$ dan pertemuan kedua sebesar $88,61 \%$ dengan kriteria sangat aktif. Hasil analisis lembar angket strategi pembelajaran superitem dengan kriteria sangat tinggi.
\end{abstract}

Kata Kunci : Superitem, kemampuan pemecahan masalah matematis siswa, aktivitas, minat.

\section{Pendahuluan}

Matematika mempunyai ciri khas yang berkaitan dengan ide-ide atau konsep-konsep abstrak yang tersususn secara hirarkis. Matematika merupakan ilmu dasar yang harus dikuasai oleh peserta didik karena matematika tidak bisa lepas dari kehidupan dan matematika selalu berkaitan dengan perkembangan ilmu lainnya. Oleh karena itu, matematika diajarkan dari jenjang Sekolah Dasar (SD) sampai ke jenjang pendidikan yang lebih tinggi. Hal ini sejalan dengan pendapat (Rosmaiyadi, 2017) yang menyatakan bahwa peserta didik mulai dari Sekolah Dasar (SD) perlu diberikan mata pelajaran matematika sebagai bekal peserta didik untuk dapat berpikir logis, analitis, kritis, inovatif dan kreatif.

Dalam standar isi Peraturan Menteri Pendidikan Nasional Republik Indonesia Nomor 20 tahun 2006 menyebutkan bahwa salah satu tujuan pembelajaran matematika adalah agar peserta didik mempunyai kemampuan memecahkan masalah yang meliputi kemampuan memahami masalah, merancang model matematika, menyelesaikan model dan menafsirkan solusi yang diperoleh. National Council of Teachers of Mathematics (NCTM; 2000) juga menetapkan lima standar kemampuan matematis yang harus di miliki peserta didik satu diantaranya yaitu kemampuan pemecahan masalah matematis.

Menurut Hartono, (2014) kemampuan pemecahan masalah sangat penting karena dengan kemampuan pemecahan masalah siswa akan memperoleh pengalaman dalam menggunakan keterampilan dan pengetahuannya yang dimiliki untuk memecahkan masalah atau menyelesaikan soalsoal yangt tidak rutin. Maka dari itu pemecahan masalah merupakan bagian dari kurikulum matematika.

Adapun pentingnya kemampuan pemecahan masalah oleh siswa dalam matematika yang dikemukakan oleh Branca (Syaiful, 2012) yaitu: (1) kemampuan pemecahan masalah merupakan jantungnya matematika dan merupakan tujuan umum pengajaran matematika,; (2) di dalam pemecahan masalah terdapat metode, prosedur, dan strategi yang merupakan proses inti dan utama dalam kurikulum 


\section{- - - Jurnal Pendidikan Matematika Indonesia \\ Volum 4 Nomor 2 bulan September 2019 Page 62 - 67 \\ p-ISSN: 2477-5967 e-ISSN: 2477-8443}

matematika; dan (3) kemampuan dasar dalam belajar matematika adalah kemampuan pemecahan masalah.

Berdasarkan tujuan di atas dapat dilihat bahwa kemampuan pemecahan masalah matematis merupakan hal yang harus dikuasai oleh siswa. Agar dalam proses belajar mengajar siswa dapat memahami suatu permasalahan untuk menyelesaikan soal yang berhubungan dengan pemecahan masalah. sehingga siswa lebih mudah merespon, berinteraksi dan mengintegrasikan suatu konsep-konsep dan teoremateorema dalam pembelajaran matematika di sekolah.

Namun pada kenyataannya kemampuan pemecahan masalah matematis siswa di lapangan masih rendah. Hal ini dapat di lihat dari hasil prariset peneliti di SMP Negeri 8 Singkawang dimana pada indikator pertama yaitu terdapat 24 siswa $(80 \%)$ yang dapat menjawab dan 6 siswa (20\%) yang tidak dapat memahami masalah. Indikator kedua yaitu hanya terdapat 12 siswa (40\%) yang dapat menjawab dan 18 siswa $(60 \%)$ yang tidak dapat membuat rencana penyelesaian masalah. Indikator ketiga yaitu hanya terdapat 6 siswa $(20 \%)$ yang dapat menjawab dan 24 siswa $(80 \%)$ yang tidak dapat melaksanakan rencana penyelesaian masalah. Indikator yang keempat terdapat $30(100 \%)$ siswa yang tidak dapat menjelaskan atau menginterpretasikan hasil penyelesaian dari jawaban yang diperoleh.

Rendahnya kemampuan pemecahan masalah matematis siswa dapat di sebabkan karena aktivitas dan minat siswa masih rendah dalam proses pembelajaran. Hal ini di perkuat dari hasil observasi dan wawancara peneliti di sekolah. Adapun hasil observasi yang di peroleh peneliti adalah pada saat proses pembelajaran di kelas terlihat bahwa masih banyak siswa yang kurang menanggapi penjelasan dan pertanyaanpertanyaan yang di berikan oleh guru. Selain itu saat guru memberikan soal-soal latihan siswa cenderung mengikuti langkah-langkah yang diberikan oleh guru, sehingga saat diberikan soal yang sedikit berbeda masih banyak siswa yang tidak bias menjawab. Hal ini akan berdampak pada nilai yang didapat tidak sesuai dengan yang diharapkan. Padahal menurut Tahir (2012) menyatakan bahwa aktivitas belajar merupakan tingkah laku yag bersifat fisik seseorang untuk mencapai tujuan yang akan mempengaruhi adanya perubahan pada dirinya, karena adanya interaksi antara individu dengan individu maupun individu dengan lingkungannya.

Selain itu peneliti juga melihat kurangnya minat siswa terhadap pembelajaran matematika. Berdasarkan hasil wawancara terhadap siswa kelas VII A, kurangnya minat ini ditandai dengan banyak siswa yang tidak semangat dan kurang memperhatikan terhadap pembelajaran yang berlangsung serta merasa bosan dan merasa pelajaran matematika itu sulit. Padahal minat merupakan hal penting dalam proses pembelajaran matematika. Tentunya masalah ini sering kali menghambat pembelajaran dan menyebabkan rendahnya kemampuan pemecahan masalah matematis siswa. Sardiman (2014) menyatakan bahwa dengan adanya minat proses pembelajaran akan berjalan lancar

Strategi pembelajaran Superitem merupakan pembelajaran yang dimulai dari pemberian soal-soal yang sederhana kemudian meningkat pada kriteria soal-soal yang lebih kompleks. Pembelajaran tersebut menggunakan soal- soal bentuk superitem, di mana pada satu superitem terdiri dari beberapa item yang soalnya dari tahapan yang sederhana ke tahapan yang lebih kompleks. (Miftahul, 2014). Alternative ini di rancang untuk membantu peserta didik dalam memecahkan soal, memahami hubungan antar konsep dan membantu kematangan penalaran siswa dalam memecahkan masalah.

Hasil penelitian yang dilakukan oleh Mulawarni, dkk (2012) diperoleh bahwa pembelajaran matematika dengan strategi pembelajaran superitem kemampuan siswa dalam memecahkan masalah pertidaksamaan linear satu variabel berdasarkan tes superitem berbeda-beda pada tiap indikator, semakin tinggi kognitif siswa maka semakin tinggi kemampuan siswa dalam memecahkan masalah. Siswa dengan kemampuan tinggi kemampuan dalam memecahkan masalah kubus dan balok dengan menggunakan tes superitem berdasarkan taksonomi solo dapat mencapai level unistruktural hingga level abstrack, hal ini dapat dilihat dari tes yaitu siswa dengan kemampuan yang tinggi dapat memenuhi semua indikator tes superitem. Berdasarkan latar belakang permasalahan yang telah dipaparkan peneliti maka peneliti tertarik untuk melakukan penelitian dengan judul "Pengaruh Strategi Pembelajaran Superitem Terhadap Kemampuan Pemecahan Masalah Matematis Siswa Pada Materi Pertidaksamaan Linear Satu Variabel Kelas VII SMP Negeri 8 Singkawang".

\section{METODE}

Jenis penelitian yang digunakan dalam penelitian ini adalah penelitian kuantitatif dengan metode eksperimen. Penelitian ini menggunakan bentuk penelitian quasi eksperimental design dengan rancangan the nonequivalent posstest-only control group design dikarenakan fokus dalam penelitian adalah untuk mengetahui kemampuan pemecahan masalah matematis siswa berdasarkan hasil posstest pada kelas eksperimen setelah dikenakan strategi pembelajaran superitem dan kelas kontrol setelah dikenakan model pembelajaran langsung. Adapun sekolah yang menjadi tempat penelitian adalah SMP Negeri 8 Singkawang kelas VII Populasi yang digunakan dalam penelitian ini adalah semua peserta didik kelas VII SMP Negeri 08 Singkawang yang terdiri dari lima kelas, yaitu kelas VIIA, VIIB, VIIC, VIID dan VIIE yang berjumlah 135 siswa. Teknik pengambilan sampel yang digunakan adalah Purposive Sampling. Dari hasil pertimbangan guru dengan melihat hasil ulangan harian diperoleh kelas VIIA sebagai kelas eksperimen dan VIIB sebagai kelas kontrol.

Penelitian ini menggunakan teknik analisis data kuantitatif dengan teknik statistik. Data kuantitatif di peroleh dari pemberian test kemampuan pemecahan masalah matematis siswa yang di analisis dengan menggunakan uji effect size. Sedangkan lembar observasi yang digunakan dalam penelitian ini yaitu lembar aktivitas proses pembelajaran strategi superitem dan lembar angket untuk melihat minat siswa terhadap pembelajaran yang di analisis menggunakan teknik statistik. 


\section{- - - Jurnal Pendidikan Matematika Indonesia \\ Volum 4 Nomor 2 bulan September 2019 Page 62 - 67 \\ p-ISSN: 2477-5967 e-ISSN: 2477-8443}

\section{HASIL DAN PEMBAHASAN}

\section{A. Kemampuan Pemecahan Masalah Matematis Siswa}

Penelitian ini memperoleh data hasil posttest dari dua kelas yaitu kelas yang diajarkan dengan strategi pembelajaran superitemdan kelas yang diajarkan dengan pembelajaran langsung. Adapun posttest yang diberikan berbentuk soal tes kemampuan pemecahan masalah matematis siswa yang mengandung empat indikator kemampuan pemecaham masalah matematis siswa.

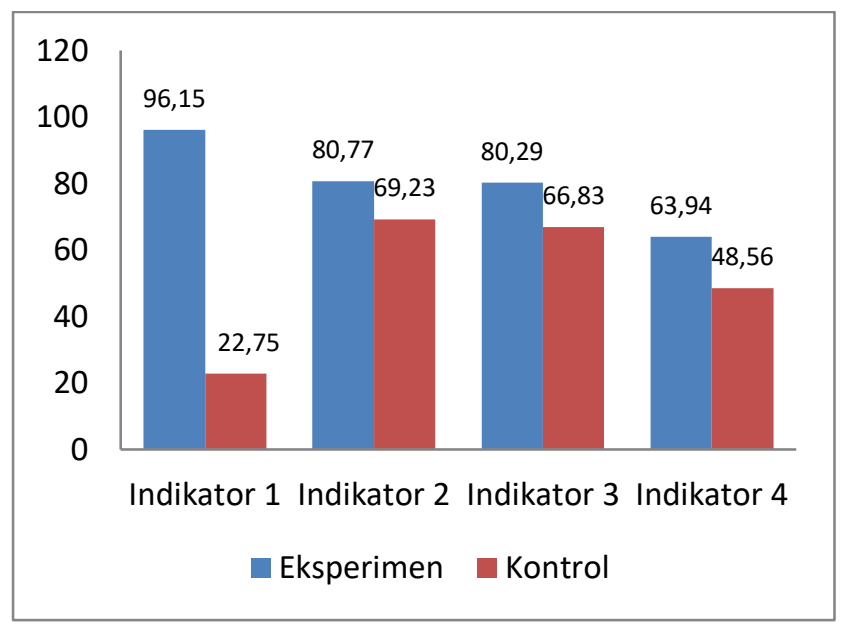

Gambar 1. Diagram Batang Persentase Kemampuan Pemecahan Masalah Matematis Siswa Tiap Indikator Kelas Eksperimen dan Kelas Kontrol

Dari gambar 1 menunjukkan bahwa tiap indikator kemampuan pemecahan masalah matematis siswa antara kelas eksperimen dan kelas kontrol berbeda. Kemampuan pemecahan masalah matematis siswa pada kelas eksperimen terlihat lebih baik dari kelas kontrol terutama pada indikator pertama yaitu indikator mengidentifikasi unsur-unsur yang diketahui, ditanyakan dan kecukupan unsur yang diperlukan. Untuk melihat perbedaan kemampuan pemecahan masalah matematis siswa secara signifikan antara kelas ekperimen dan kelas kontrol maka selanjutnya menggunakan uji-t dua sampel independen. Dengan sebelumnya terlebih dahulu dilakukan uji normalitas dan uji homogenita. Berdasarkan hasil perhitungan, untuk data posttest kelas eksperimen dan kontrol disajikan ada Tabel I sebagai berikut:

TABEL I

REKAPITULASI PERHITUNGAN UJI NORMALITAS KELAS EKSPERIMEN DAN KONTROL

\begin{tabular}{ccccc}
\hline Kelompok & $\mathrm{N}$ & $\begin{array}{c}x^{2} \\
\text { Hitung }\end{array}$ & $\begin{array}{c}x^{2} \\
\text { Tabel }\end{array}$ & Kesimpulan \\
\hline Eksperimen & 26 & $-31,90$ & 7,81 & $\begin{array}{c}\text { Data Berdistribusi } \\
\text { Normal }\end{array}$ \\
Kontrol & 26 & $-18,38$ & 7,81 & $\begin{array}{c}\text { Data Berdistribusi } \\
\text { Normal }\end{array}$ \\
\hline
\end{tabular}

Dari Tabel I diketahui bahwa data posttest kelas eksperimen dan kelas kontol berdistribusi tidak normal. Maka untuk mengetahui perbedaan penggunaan strategi pembelajaran Superitem dan model pembelajaran langsung peneliti menggunakan uji Chi-Kuadrat. Adapun rekapitulasi hasil perhitungan perbedaan penggunaan strategi pembelajaran Superitem dan model pembelajaran langsung terhadap kemampuan pemecahan masalah matematis siswa dapat dilihat pada Tabel II berikut.

TABEL II

REKAPITULASI PERHITUNGAN UII T

\begin{tabular}{cccccc}
\hline Kelompok & Db & Dsg & $\begin{array}{c}\text { Taraf } \\
\text { Signifikan }\end{array}$ & $\mathrm{T}_{\text {hitung }}$ & $\mathrm{T}_{\text {tabel }}$ \\
\hline $\begin{array}{l}\text { Eksperimen } \\
\text { dan Kontrol }\end{array}$ & 60 & 6,57 & $5 \%$ & 6,73 & 1,68 \\
\hline
\end{tabular}

Dari Tabel II di atas terlihat bahwa nilai $\mathrm{T}_{\text {hitung }}=6,73$. Berdasarkan kriteria pengujian maka penggunaan strategi pembelajaran Superitem dan model pembelajaran langsung terhadap kemampuan pemecahan masalah matematis siswa dikatakan memiliki perbedaan apabila $\mathrm{T}_{\text {hitung }}>\mathrm{T}_{\text {tabel. }}$. Dapat disimpulkan bahwa terdapat perbedaan penggunaan strategi pembelajaran Superitem dan model pembelajaran langsung terhadap kemampuan pemecahan masalah matematis siswa pada materi PtLSV kelas VII SMP Negeri 8 Singkawang.

Perbedaan kemampuan pemecahan masalah matematis siswa antara kelas eksperimen dan kelas kontrol disebabkan karena pada langkah-langkah strategi pembelajaran Superitem melatih siswa dalam memecahkan masalah karena pada proses pembelajarannya siswa dilatih mengerjakan dari soal-soal yang sederhana meningkat ke yang lebih kompleks. Hal ini sesuai dengan apa yang menjadi satu diantara kelebihan strategi pembelajaran superitem yaitu dapat memberi kesempatan kepada siswa untuk memahami situasi permasalahan secara bertahap sesuai dengan kesiapannya (Miftahul, 2014).

Selanjutnya untuk melihat seberapa besar pengaruh strategi pembelajaran Superitem terhadap kemampuan pemecahan masalah matematis siswa, maka digunakan rumus Effect Size. Adapun hasil perhitungan Effect Size dapat dilihat pada Tabel III sebagai berikut.

TABEL III

REKAPITULASI HASIL UJI EFFECT SIZE

\begin{tabular}{ccccc}
\hline Kelas & $\begin{array}{c}\text { Nilai } \\
\text { Rata-rata }\end{array}$ & $\begin{array}{c}\text { Standar Deviasi } \\
\text { Kelas Kontrol }\end{array}$ & ES & Kriteria \\
\hline Eksperimen & 80,28 & 6,45 & 1,88 & Tinggi \\
Kontrol & 68,03 & & & \\
\hline
\end{tabular}

Dari Tabel III dapat dilihat bahwa hasil perhitungan Effect Size $=1,88$ dengan kriteria tinggi karena 1,88 berada pada $E S \geq 0,8$. Ini berarti strategi pembelajaran Superitem memberikan pengaruh terhadap kemampuan pemecahan masalah matematis siswa yaitu sebesar 1,88 yang masuk pada kriteria tinggi.

Hasil ini sejalan dengan penelitian Permatasari (2014) dimana penelitiannya menunjukkan bahwa rata-rata hasil belajar siswa yang diajar dengan menggunakan strategi 


\section{- - - Jurnal Pendidikan Matematika Indonesia \\ Volum 4 Nomor 2 bulan September 2019 Page 62 - 67 \\ p-ISSN: 2477-5967 e-ISSN: 2477-8443}

pembelajaran Superitem berada pada kategori tinggi yaitu 72,46 .

\section{B. Aktivitas Belajar Siswa}

Untuk mengetahui aktivitas siswa selama mengikuti strategi pembelajaran superitem peneliti menggunakan lembar observasi yang dilakukan selama dua kali pertemuan dan diamati oleh 2 oberver. Adapun hasil observasi aktivias belajar siswa yang dilakukan peneliti dapat dilihat pada tabel IV sebagai berikut.

TABEL IV

Rekapitulasi Persentase Pengamatan Aktivitas Siswa PERTEMUAN PERTAMA DAN KEDUA

\begin{tabular}{cccc}
\hline No & Kategori Pengamatan & Pertemuan 1 & Pertemuan 2 \\
\hline 1 & Aktivitas visual & $86,89 \%$ & $92,59 \%$ \\
2 & Aktivitas berbicara & $70,51 \%$ & $75,64 \%$ \\
3 & Aktivitas menulis & $85,90 \%$ & $91,99 \%$ \\
4 & Aktivitas bergerak & $94,87 \%$ & $94,23 \%$ \\
\hline \multicolumn{5}{c}{ Rata-Rata } & $84,54 \%$ & $88,61 \%$ \\
\hline
\end{tabular}

Dari Tabel IV dapat dilihat persentase rata-rata aktivitas pada pertemuan pertama dan kedua pada kategori pengamatan aktivitas visual diperoleh persentase sebesar $86,89 \%$ pada pertemuan pertama dan $92,56 \%$ pada pertemuan kedua. Pada kategori pengamatan aktivitas berbicara diperoleh persentase $70,51 \%$ pada pertemuan pertama dan 75,64\% untuk pertemuan kedua. Pada kategori pengamatan aktivias menulis diperoleh $85,90 \%$ pada pertemuan pertama dan $91,99 \%$ pada pertemuan kedua. Pada kategori pengamatan aktivitas bergerak diperoleh $94,87 \%$ pada pertemuan pertama dan 94,23 pada pertemuan kedua.

Dari tiga observer rata-rata yang diperoleh untuk pertemuan 1 adalah sebesar 84,54\%, sedangkan rata-rata untuk pertemuan 2 dengan tiga observer adalah sebesar $88,61 \%$. Maka dapat disimpulkan bahwa aktivitas belajar siswa setelah diberikan strategi pembelajaran superitem menjadi aktif pada materi pertidaksamaan linear satu variabel.

Hasil ini sejalan dengan Mulawarni, dkk (2012) menyatakan bahwa persentase aktivitas siswa pada strategi pembelajaran superitem kelas eksperimen pada pertemuan pertama dan kedua berada pada kriteria sangat aktif.

\section{Minat Belajar Siswa}

Angket minat belajar siswa dalam penelitian ini merupakan angket yang hanya diberikan kepada siswa kelas eksperimen untuk mengetahui seberapa besar minat siswa dengan diterapkan strategi superitem. Angket minat belajar tersebut merupakan angket tertutup dan siswa hanya memilih satu jawaban dari 5 pilihan yang diberikan (sangat setuju, setuju, ragu-ragu, tidak setuju, dan sangat tidak setuju) yang telah disediakan. Angket minat yang digunakan berupa pernyataan positif dan pernyataan negatif yang berjumlah 14 pernyataan terdiri dari 6 indikator minat belajar.

Hasil perhitungan rata-rata persentase angket minat belajar siswa ada pernyataan positif pada kelas eksperimen dapat dilihat pada Tabel V sebagai berikut.
TABEL V

REKAPITULASI HASIL ANGKET MINAT SISWA UNTUK PERNYATAAN POSITIF

\begin{tabular}{|c|c|c|c|c|c|c|c|}
\hline \multirow[t]{2}{*}{ Indikator } & \multicolumn{5}{|c|}{ Pilihan } & \multirow[t]{2}{*}{ Persentase } & \multirow{2}{*}{$\begin{array}{c}\text { Kriteri } \\
\text { a }\end{array}$} \\
\hline & SS & $\bar{S}$ & RR & TS & STS & & \\
\hline Perhatian & 32 & 42 & 4 & 0 & 0 & 87 & $\begin{array}{l}\text { Sangat } \\
\text { Tinggi }\end{array}$ \\
\hline Rasa Senang & 15 & 49 & 14 & 0 & 0 & 80,3 & Tinggi \\
\hline $\begin{array}{l}\text { Keingintahua } \\
\mathrm{n}\end{array}$ & 7 & 19 & 0 & 0 & 0 & 85 & $\begin{array}{l}\text { Sangat } \\
\text { Tinggi }\end{array}$ \\
\hline \multicolumn{6}{|c|}{ Rata-Rata Keseluruhan } & 84,1 & Tinggi \\
\hline
\end{tabular}

Dari Tabel V dapat dilihat bahwa minat belajar siswa untuk pernyataan positif pada indikator 1 perhatian yaitu mencakup aspek berusaha memahami pembelajaran matematika, mengerjakan soal-soal yang diberikan dan memahami manfaat belajar matematika untuk kategori pilihan sangat setuju dengan jumlah siswa 32, kategori setuju dengan jumlah siswa 42 dan kategori ragu-ragu dengan jumlah siswa 4 dari 3 pernyataan. Pada indikator 2 rasa senang yaitu bersemangat mengikuti pembelajaran dan lebih memilih membaca buku matematika dari pada bermain untuk kategori pilihan sangat setuju dengan jumlah siswa 15, kategori setuju dengan jumlah siswa 49 dan ketegori ragu-ragu dengan jumlah siswa 14 dari 2 pernyataan. Pada indikator 3 keingintahuan yaitu bertanya kepada guru atau teman untuk kategori pilihan sangat setuju dengan jumlah siswa 7 dan kategori setuju dengan jumlah siswa 19 dari 1 pernyataan. Jumlah siswa 26 orang menghasilkan rata-rata persentase keseluruhan siswa adalah $84,1 \%$ yang memiliki kriteria tinggi karena berada pada kisaran $70 \% \leq \mathrm{p} \leq 85 \%$. Selanjutnya untuk hasil perhitungan rata-rata angket minat belajar siswa pernyataan negatif pada kelas eksperimen dapat dilihat pada Tabel VI berikut.

TABEL VI

REKAPITULASI HASIL ANGKET MinAt SisWA UNTUK PERNYATAAN NEGATIF

\begin{tabular}{|c|c|c|c|c|c|c|c|}
\hline \multirow[t]{2}{*}{ Indikator } & \multicolumn{5}{|c|}{ Pilihan } & \multirow[t]{2}{*}{ Persentase } & \multirow{2}{*}{$\begin{array}{c}\text { Kriteri } \\
\text { a }\end{array}$} \\
\hline & SS & $S$ & RR & TS & STS & & \\
\hline Perhatian & 0 & 0 & 6 & 40 & 56 & 88 & $\begin{array}{l}\text { Sangat } \\
\text { Tinggi }\end{array}$ \\
\hline Rasa Senang & 0 & 0 & 6 & 25 & 21 & 86 & $\begin{array}{l}\text { Sangat } \\
\text { Tinggi }\end{array}$ \\
\hline $\begin{array}{l}\text { Keingintahua } \\
\mathrm{n}\end{array}$ & 0 & 0 & 1 & 14 & 11 & 88 & $\begin{array}{l}\text { Sangat } \\
\text { Tinggi }\end{array}$ \\
\hline & Rata- & ta & eluru & & & 87,3 & $\begin{array}{l}\text { Sangat } \\
\text { Tinggi }\end{array}$ \\
\hline
\end{tabular}

Dari Tabel VI dapat dilihat bahwa rata-rata minat belajar siswa untuk pernyataan negatif pada indikator 1 perhatian yaitu mencangkup aspek berusaha memahami pembelajaran matematika, mengerjakan soal-soal yang diberikan dan memahami manfaat belajar matematika untuk kategori pilihan sangat tidak setuju dengan jumlah siswa 56, kategori tidak setuju dengan jumlah siswa 40, kategori ragu-ragu dengan jumlah siswa 6 dari 3 pernyataan. Pada indikator 2 rasa senang yaitu bersemangat mengikuti pembelajaran dan lebih memilih membaca buku matematika dari pada bermain untuk kategori pilihan sangat tidak setuju dengan jumlah siswa 21, kategori tidak setuju dengan jumlah siswa 25, kategori raguragu dengan jumlah siswa 6 dari 2 pernyataan. Pada indikator 
3 keingintahuan yaitu bertanya kepada guru atau teman untuk kategori pilihan sangat tidak setuju dengan jumlah siswa 11, kategori tidak setuju dengan jumlah siswa 14, kategori raguragu dengan jumlah siswa 1 dari 1 pernyataan. Dengan jumlah siswa 26 orang menghasilkan rata-rata persentase keseluruhan siswa adalah $87,3 \%$ yang memiliki kriteria sangat tinggi karena berada pada kisaran $85 \% \leq p \leq 100 \%$. Secara keseluruhan rata-rata minat belajar siswa baik dari pernyataan positif dan pernyataan negatif dapat dilihat pada Tabel VII berikut ini.

TABEL VII

ReKaPITUlasi Hasil ANGKet Minat Siswa untuk SElURUH INDIKATOR

\begin{tabular}{|c|c|c|c|c|c|c|c|}
\hline \multirow{2}{*}{ Motivasi } & \multicolumn{5}{|c|}{ Pilihan } & \multirow{2}{*}{$\begin{array}{l}\text { Rata- } \\
\text { rata }\end{array}$} & \multirow{2}{*}{ Kriteria } \\
\hline & SS & $S$ & RR & $\mathrm{TS}$ & STS & & \\
\hline Positif & 54 & 110 & 18 & 0 & 0 & 84,1 & $\begin{array}{l}\text { Sangat } \\
\text { Tinggi } \\
\text { Sangat }\end{array}$ \\
\hline Negatif & 88 & 79 & 13 & 0 & 0 & 87,3 & Tinggi \\
\hline \multicolumn{6}{|c|}{ Rata-Rata Keseluruhan } & 85,7 & $\begin{array}{l}\text { Sangat } \\
\text { Tinggi }\end{array}$ \\
\hline
\end{tabular}

Dari Tabel VII dapat dilihat bahwa rata-rata minat belajar siswa untuk pernyataan positif dan pernyataan negatif pada semua indikator berada pada kriteria sangat tinggi dengan jumlah siswa 26 orang menghasilkan rata-rata keseluruhan siswa adalah $85,7 \%$ yang memiliki kriteria sangat tinggi karena berada pada kisaran $85 \% \leq \mathrm{p} \leq 100 \%$.

Hal ini sejalan dengan pendapat Agustin (2014) menyatakan bahwa minat belajar siswa mempengaruhi hasil belajar siswa dimana jika minat belajar siswa tinngi maka semakin tinggi hasil belajar siswa, begitu pula sebaliknya semakin rendah minat belajar maka hasil belajar siswa akan rendah pula

\section{KESIMPULAN}

Berdasarkan hasil analisis data dan pembahasan secara umum dapat disimpulkan bahwa strategi pembelajaran superitem dapat memberikan pengaruh yang tinggi terhadap kemampuan pemecahan masalah matematis siswa pada materi pertidaksamaan linear satu variabel kelas VII SMP Negeri 8 Singkawang. Adapun kesimpulan secara khusus dari penelitian ini adalah sebagai berikut.

1. Terdapat perbedaan kemampuan pemecahan masalah matematis siswa antara siswa mendapatkan strategi pembelajaran superitem dengan siswa yang mendapatkan model pembelajaran langsung pada materi pertidaksamaan linear satu variabel kelas VII SMP Negeri 8 Singkawang.

2. Strategi pembelajaran superitem memiliki pengaruh tinggi terhadap kemampuan pemecahan masalah matematis siswa pada materi pertidaksamaan linear satu variabel kelas VII SMP Negeri 8 Sningkawang.

3. Aktivitas belajar siswa sangat aktif setelah diberikan strategi pembelajaran superitem pada materi pertidaksamaan linear satu variabel kelas VII SMP Negeri 8 Singkawang.

4. Minat belajar siswa positif terhadap strategi pembelajaran superitem dengan rata-rata persentase pernyataan termasuk pada kriteria sangat tinggi.

\section{UCAPAN TERIMAKASIH}

Penulis mengucapkan terima kasih kepada Ketua STKIP Singkawang Drs. Andi Mursidi, M.Si yang telah memberikan arahan dalam penulisan artikel hasil penelitian ini, dan kepada guru kelas SMP Negeri 8 Singkawang yang telah membantu perijinan dan informasi selama dalam proses penelitian.

\section{DAFTAR PUSTAKA}

Agustin, Denik (2014). Pengaruh Minat Belajar dan Lingkungan Sekolah Terhadap Prestasi Belajar Ekonomi Pada Siswa Kelas VIII MTs Muhammadiyah Waru Tahun. Jurnal Publikasi. Pendidikan Ekonomi Akuntansi Fakultas Keguruan dan Ilmu Pendidikan Universsitas Muhammadiyah Surakarta.

Hartono, Yusuf. (2014). Matematika StrategiPemecahan Masalah. Yogyakarta: Graha Ilmu.

Mifhatul. (2014). Model-Model Pengajaran Dan Pembelajaran.Yogyakarta : Pustaka Pelajar.

Mulawarni, dkk. (2012). Penggunaan Tes Superitem untuk Menilai Kemampuan Siswa Dalam Memecahkan Masalah Matematika Khususnya Pada Materi Kubus dan Balok di SMP Negeri 2 Taluditi. Jurnal Pendidikan Matematika. F.MIPA Universitas Negeri Gorontalo.

NCTM. (2000). Principles and Standars for School Mathematics. Reston: inc. 906 Association Drive.

Permatasari. (2014). Efektifitas Penerapan Model Pembelajaran Superitem Dalam Meningkatkan Pemahaman Konsep Matematika Siswa Kelas X SMA N 11 Makassar. Mapan 2 (1) 2014

Permendiknas No. 22 Tahun 2006. Standar Isi untuk Satuan Pendidikan Dasar dan Menengah. Jakarta: BSNP

Rosmaiyadi. (2017). Analisis Kemampuan Berpikir Kritis Matematis Siswa dalam Learning Cycle $7 E$ Berdasarkan Gaya Belajar. Jurnal Pendidikan Matematika Indonesia 2 (1) Tahun 2017.

Sardiman. (2014). Interaksi \& Motivasi Belajar Mengajar. Jakarta: PT Rajagrafindo Persada

Syaiful. (2012). Peningkatan Kemampuan Pemecahan Masalah Matematis Melalui Pendekatan PendidikanMatematika Realistik. 
http://eprints.uny.ac.id/7201/ (diakses 22 Maret 2018)

Tahir,W.M. (2012). "Peningkatan Aktivitas Belajar Siswa Menggunakan Media Kartu Bilangan Pada Pembelajaran Matematika". Skripsi. Pontianak: Fakultas Keguruan dan Ilmu Pendidikan, Universitas Tanjungpura 